Canadian Journal of Bioethics

C. B Canadian Journal of Bioethics

Revue canadienne de bioéthique

\title{
Canadian Physiotherapists Want to Talk More About Equity
}

Shaun Cleaver, Simon Deslauriers and Anne Hudon

Volume 1, Number 3, 2018

Pourtours et défis d'une éthique en réadaptation

Limits and Challenges of an Ethics in Rehabilitation

URI: https://id.erudit.org/iderudit/1058255ar

DOI: https://doi.org/10.7202/1058255ar

See table of contents

Publisher(s)

Programmes de bioéthique, École de santé publique de l'Université de Montréal

ISSN

2561-4665 (digital)

Explore this journal

Cite this document

Cleaver, S., Deslauriers, S. \& Hudon, A. (2018). Canadian Physiotherapists Want to Talk More About Equity. Canadian Journal of Bioethics / Revue canadienne de bioéthique, 1(3), 90-91. https://doi.org/10.7202/1058255ar

All Rights Reserved (c) Shaun Cleaver, Simon Deslauriers, Anne Hudon, 2018

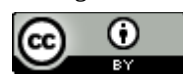

This document is protected by copyright law. Use of the services of Érudit (including reproduction) is subject to its terms and conditions, which can be viewed online.

https://apropos.erudit.org/en/users/policy-on-use/ 


\title{
LETTRE À L'ÉDITEUR / LETTER TO THE EDITOR
}

\section{Canadian Physiotherapists Want to Talk More About Equity}

\author{
Shaun Cleaver ${ }^{1}$, Simon Deslauriers ${ }^{2,3}$, Anne Hudon ${ }^{4,5}$ \\ Mots clés \\ physiothérapie, équité, justice, mobilisation professionnelle \\ Keywords \\ physiotherapy, equity, justice, professional mobilisation
}

Dear Editors of this Special Issue on Ethics in Rehabilitation,

We are writing this letter as physiotherapists and members of a profession that has, until recently, evolved in the constrained boundaries of the logic of biomedicine [1] and that has aspired to greater prominence in health systems within jurisdictions and globally [2] through building confidence in the value and effectiveness of its services [3]. While the physiotherapy profession has concentrated its efforts in fulfilling these aspirations, we believe that only limited attention has been given to other crucial aspects of the practice such as equity and the equitable distribution of their services. We believe that it is time for the profession to discuss current equity issues and to start building concrete steps to address them.

Meanwhile, in Canada we are seeing a continuous shift of the profession away from the public sector, towards mostly for-profit private practice that is supported primarily by user-pay models of service delivery [4]. Consistent with this shift, waiting lists are growing for public physiotherapy services, with extensive waiting times reported in Québec and Ontario [5,6]. This trend means that the level of access to physiotherapy services increasingly depends on the patients' ability to pay. Despite evidence about the incidence of such inequities, discussions about equity in the profession have thus far been rare and given marginal attention.

In order to raise awareness and stimulate discussion, we led a workshop on the subject of equity in physiotherapy at the Canadian Physiotherapy Congress held in November 2018 in Montreal. The workshop, entitled Canadian Physiotherapists Face up to Inequities in Service Provision: Discussion and Call to Action!, brought together 55 participants concerned with this issue. The workshop was a combination of plenary and small group activities to incite discussion and exchange. At the conclusion of the session, participants were invited to write down their perspectives on equity in physiotherapy and comment on the workshop.

The participants identified multiple equity issues, including, but not limited to:

- Inequitable access to services for Indigenous peoples in Canada, Canadians of low socio-economic status, and Canadians living in rural and remote areas.

- Differences in service provision according to medical diagnostic categories (e.g., acute injuries versus chronic pain) and insurance providers.

- $\quad$ Health system issues such as inadequate publicly funded services and long wait lists.

Overall, participants' comments regarding the issues raised by this one-hour workshop focused on the need for more time to conduct in-depth discussions on such complex equity issues. Moreover, participants expressed great interest in continuing this conversation in the future.

As physiotherapists who have focused our careers toward promoting equity, we were pleased with the success of the workshop, but we also recognize that there is much more work to be done. By building on the workshop, reaching out to participants and collaborating with the Canadian Physiotherapy Association, we foresee multiple next steps (e.g., creation of a formal community of practice on equity, publications in professional and scientific journals, advocacy initiatives) that will help continue this conversation while simultaneously building an equity-generating movement.

We are thus thrilled that this special issue showcases the importance of ethics in rehabilitation and believe that equity should be an important piece to reflect on, when thinking about ethical provision of care. Through this letter, we wish to invite physiotherapists and rehabilitation providers across Canada, and the many readers of this special issue, to engage and join the movement to build a more equitable profession.

\section{Remerciements}

Les auteurs remercient sincèrement les participants à l'atelier pour leur participation active. Merci également aux professeurs Mike Landry (Université Duke) et Brenna Bath (Université de la Saskatchewan) pour leur contribution en tant que panélistes durant l'atelier et à Maude Laliberté pour sa contribution à l'élaboration initiale de cette initiative.

\section{Conflit d'intérêts}

Aucun à déclarer

Édition/Editors: Bryn Williams-Jones

\section{Acknowledgements}

The authors sincerely thank the workshop participants for their active engagement. Additional thanks to Dr. Mike Landry (Duke University) and Dr. Brenna Bath (University of Saskatchewan) for their contribution as panelists during the workshop and to Dr. Maude Laliberté for her contribution in the initial development of this initiative.

\section{Conflicts of Interest}

None to declare 


\section{Affiliations}

${ }^{1}$ School of Physical and Occupational Therapy, McGill University, Montréal, Canada

${ }^{2}$ Département de réadaptation, Faculté de médecine, Université Laval, Québec, Canada

${ }^{3}$ Centre interdisciplinaire de recherche en réadaptation et intégration sociale (CIRRIS), Québec, Canada

${ }^{4}$ School of Public Health and Health Systems, University of Waterloo, Waterloo, Canada

${ }^{5}$ Section de droit civil, Faculté de droit, Université d'Ottawa, Ottawa, Canada

Correspondance / Correspondence: Shaun Cleaver, shauncleaver@gmail.com

Reçu/Received: 10 Dec 2018

Publié/Published: 14 Dec 2018

Les éditeurs suivront les recommandations et les procédures décrites The editors follow the recommendations and procedures outlined in dans le Code of Conduct and Best Practice Guidelines for Journal the COPE Code of Conduct and Best Practice Guidelines for Journal Editors de COPE. Plus précisément, ils travaillent pour s'assurer des Editors. Specifically, the editors will work to ensure the highest ethical plus hautes normes éthiques de la publication, y compris l'identification standards of publication, including: the identification and management et la gestion des conflits d'intérêts (pour les éditeurs et pour les of conflicts of interest (for editors and for authors), the fair evaluation auteurs), la juste évaluation des manuscrits et la publication de of manuscripts, and the publication of manuscripts that meet the manuscrits qui répondent aux normes d'excellence de la revue. journal's standards of excellence.

\section{References}

1. Gibson BE, Nicholls DA, Setchell J, Groven KS. Working against the grain: Criticality for an otherwise physiotherapy. In: Manipulating Practices: A Critical Physiotherapy Reader, edited by BE Gibson, DA Nicholls, J Setchell, KS Groven. Oslo, Norway: Cappelen Damm Akademisk. 2018:14-32.

2. World Confederation of Physical Therapy. Recognition of the profession is a global concern for physical therapists. 7 March 2016.

3. Jette AM. The Role of Nonpharmacological Approaches to Pain Management. Physical Therapy. 2018;98(11):9078.

4. Landry MD, Williams AP, Verrier MC, Holyoke P, Zakus D, Deber RB. Shifting sands: assessing the balance between public, private not-for-profit and private for-profit physical therapy delivery in Ontario, Canada. Physiotherapy Research International. 2008;13(3):189-99. 